\title{
Eco-Innovation Determination based on Structural Equation Modeling: Identifying the Mediation and Moderation Effect
}

\author{
Ma Ding, Ye Jianmu \\ Wuhan University of Technology, Wuhan, China \\ Corresponding author (e-mail): shengxin0729@163.com
}

\begin{abstract}
The motivation of enterprise eco-innovation is always an intriguing topic for policy makers, regulators, and scholars. Utilizing the rationale of institutional theory, stakeholder theory as well as upper echelons theory, this study devises a conceptualized model in explaining ecoinnovation and uses questionnaire data from 288 enterprises in Wuhan city to test the hypothetical model through Structural Equation Modeling analysis. The study reveals that both institutional/stakeholder force and organizational force are significant triggers in enterprise ecoinnovation, as the latter one mediates the effect of the former one. Supervisory support does not strengthen the relationship between institutional/stakeholder force and firm eco-innovation, yet weakens the relationship between organizational driver and eco-innovation. Conclusions imply that firm should prepare in terms of technological capability, scientific or social networking, resource base and specificity to better embrace eco-innovation, whereas governments should commit to optimize its regulation setting, law enforcement and various administrative and economic instruments to better incentivize enterprises to engage in eco-innovations.
\end{abstract}

Key words: Eco-innovation, Innovation drivers, Mediation effect, Moderation effect, Structural equation modeling 


\section{Introduction}

China has undergone economic boom in the past decades largely at the expense of environmental degradation and resource depletion. Industry pollution is mainly responsible for the negative byproduct of China's economic miracle as it is reported that $80 \%$ of the environmental contamination comes from firm production and operation. Given the backdrop of economic transition, industry upgrading, and sustainable development, it is highly imperative for Chinese enterprise to take active measures in balancing environment and economic performance. One possible solution is eco-innovation, that is, the creation or application of novel products, processes, services, organizational structures, institutional arrangement, as well as social structure with lower environmental impacts (OECD, 2009). Eco-innovation has gained increasing academic attention among which the motivation research is the most flourishing one. Scholars seek to explain the incentives of environmental innovation through plenty of empirical studies, ranging from the early stressing of environmental regulations (e.g. tax, emissions charge and standard, emission trade permit), market and technology push (e.g. retailor requirement, customer satisfaction, exportorientation, and external competitive pressure) (Cleff and Rennings, 1999, Popp, 2002/2003, Rehfeld and Rennings, 2007, Frondel et al. 2007, Frondel et al. 2008) to the recent focus on organizational (e.g. corporation strategy, organization structure, resource and capability) (Hofmann et al. 2012, Berrone et al. 2013, Cai and Zhou, 2014) and individual drivers (supervisory support, awareness, ethics) (Chang, 2011, Gadenne et al. 2009, Ramus and Steger, 2000). The theories intersecting innovation, management and environmental economics literature are comprised of institutional theory, stakeholder theory, resource based view (RBV), upper echelons theory and theory of planned behavior. While current literature provides multi-angled studies about incentives underlying eco-innovation, there remain some limitations. First of all, existing literature mainly explores the direct relationship between theory proxies and eco-innovation. Only few studies investigate the interaction effect, moderation effect, and mediation effect among determinants with the exception of studies by Berrone et al. (2013) and Cai and Zhou (2014), thus, leaving the inner mechanism of eco-innovation stimuli unclear. Furthermore, the lion's share of the present research utilizes institutional as well as organizational theories, yet, little is known about the role an individual 
plays in boosting proactive environmental response. Therefore, our study aims to explore the exante factors in eco-innovation in the context of largest emerging economy, namely, China. By utilizing the Structural Equation Modeling, this study proposes a framework constructed by integration of institutional theory, RBV, and upper echelons theory. Our study uses a survey data of 288 firms in testing our hypothesis. This explorative research intends to shed light on multi-level and multi-angle eco-innovation incentives and facilitates regulators' and policy makers' work in stimulating eco-innovation.

\section{Theoretical foundation and hypotheses development}

\subsection{Institutional and stakeholder drivers}

According to institutional theory, firms which are susceptible to social influence seek approval and legitimacy and this, in turn, induces firms to implement socially valuable environmental practices in spite of efficiency and financial consideration (Berrone et al. 2013). This theory explains why firms engage in economically unjustified environmental practices in response to strong regulatory and normative pressures. Regulations have been theoretically and empirically identified as an important driving force of environmental innovations. Porter (1991) claims that well-designed and stringent enforcement and regulation spur innovation and this innovation would offer competitive edge to the firm which in the end outweighs its cost of compliance. Cleff and Rennings (1999) argues that environment-related process innovation is mainly determined by regulation, and so-called 'soft' regulation (e.g. labels, eco-audits) on product-integrated environmental innovation can be discerned. Stakeholder theory stressing the interaction of organization with outside world argues that firms will address the expectation and interest of the stakeholder according to their power, legitimacy and emergency of appeal in order to ensure firm viability. The rationale here is that stakeholder embeds in the nexus of implicit and explicit contracts within the firm, and they provide firm with special critical resources and distinguished legitimate claim (Lin et al. 2014). The stakeholder theory incorporating regulatory compliance, consumer satisfaction and competitiveness constitutes a complementarity of the institutional theory. Hence, we argue that: 
Hypothesis 1 Institutional and stakeholder pressure positively affect eco-innovation performance

\subsection{Organizational drivers}

From organizational perspective, the stand of eco-innovation stimulating literature could be divided into strategic motivation, organizational structure, and resource capability. In terms of strategic motive, path dependence has been identified as a prominent indicator, although the empirical results are inconsistent. Technological capability and environmental improvement are intertwined as novel technology often lead to productivity, quality improvement, cost reduction, technological innovation, and environmental improvement; vice versa, the requirement of clean production necessitates advanced technology (Hofmann et al., 2012). Specifically, scholars have found that technological capability proxy - R\&D activity - has significant relationship with eco-product or ecoprocess innovation (Horbach 2008/2012). With regard to organizational structure, network strength with its advantage in performance enhancements, value chain optimization, cost containment, risk reduction, growth, efficiency in innovation, interchange of knowledge and know-how, reduction of ambiguity and identification of opportunities (Hofmann et al. 2012) facilitate firms in ecoinnovation. Research has also identified that external R\&D network with retailors, universities as well as research institutes positively affect firm environmental innovation (De Marchi, 2012). Resource profile highlighted by RBV approach claims that firm's possession of rare, un-replicable, valuable, un-substitutable resource gives firms better competitive edge over its peers. Resource is perceived as the fundamental factor influencing eco-innovation (Lin et al. 2014). Following Berrone et al. (2013), we use asset specificity and organizational slack to proxy firm resource profile owing to the fact that firm environmental innovation is contingent on these two internal resource dimensions. Even though, there is a lack of liquidity and switching capability, asset specificity ensures firm to conduct particular and significant activity such as eco-innovation with durable, specialized resource. Organizational slack which represents another dimension of resource profile provide firm with resource cushion so that firm will have leeway in making strategic choice, thus, response faster and more effectively to external shocks. This also applies to eco-innovation; firm with abundant resource would secure necessary material and intellectual asset to launch ecofriendly products and process while firm with limited resource only attend its immediate and pressing needs (Berrone et al. 2013). Thus, we posit our second hypothesis: 
Hypothesis 2 Organizational factors have positive effect on eco-innovation performance

\subsection{The mediation effect of organizational drivers}

Institutional and stakeholder pressure which comes from regulations, customer environmental consciousness, supplier green support, rival pressure is easily sensed by keen and perspicacious entrepreneurs. After evaluation of its organizational capability and resource, firm can make decision on whether to launch eco-innovation or simply make the minimal commitment; to decide extent of innovation - radical or incremental. Cai and Zhou (2014) interpret the rationale as follows; presence of homogeneous external forces and the resulted firm heterogeneous response are expected to be contingent on firm's core internal capabilities. Current technological capability comprising the physical and knowledge capital stock lays prerequisite foundation for further innovations which is also known as "innovation breeds innovation"(Baumol, 2002; cite by Horbach 2008). Networking whether it is external cooperation (with suppliers and clients) or internal cross-functional collaboration integrates resource and knowledge, reduces high innovation-associated risk, aligns the interest of several parties, and serves as a solid spur to proactive environmental practices. Organizational slack allows firm adaptability to external pressure, especially, the risky and long-term horizon environmental innovations; asset specificity gives firm more sensitivity to the possibility of reputation loss, high legal cost and government sanctions resulted from incompliance with institutional and stakeholder requirements. Thus, we can postulate:

Hypothesis 3 Organizational driver mediates the effect of institutional and stakeholder drivers on ecoinnovation

\subsection{The modulating effect of executive impacts}

Eco-innovation is not financially justified as the return is explicit and the associating risk is quite high. Additionally, the regulation sanction in China is not very stringent. Therefore, firms tend to passively attend the minimal request of regulation, and the potential benefits from eco-innovation have hardly been perceived by top management. On one hand, if an enterprise deploys its resource to environmental innovation, then, the resource available to its core competitiveness will be reduced. On the other hand, to maximize firm value, executives are reluctant to devote its limited resource to environmental practices. Many studies have proven that top management attitude is a 
key driver in firm strategic decisions, and this is a widespread situation especially in China as ownership centralization is prevalent in Chinese enterprises. Top management attitude significantly influences the speed and scope of firm reaction to environmental practice (Bansal 2003). Thus, we propose:

Hypothesis 4 Supervisory support positively modulates the relationship between institutional/stakeholder impacts and eco-innovation

Hypothesis 5 Supervisory support positively modulates the relationship between organizational drivers and eco-innovation

Based on our extensive literature review, we have built a conceptual model for this study the following way (Figure 2-1).

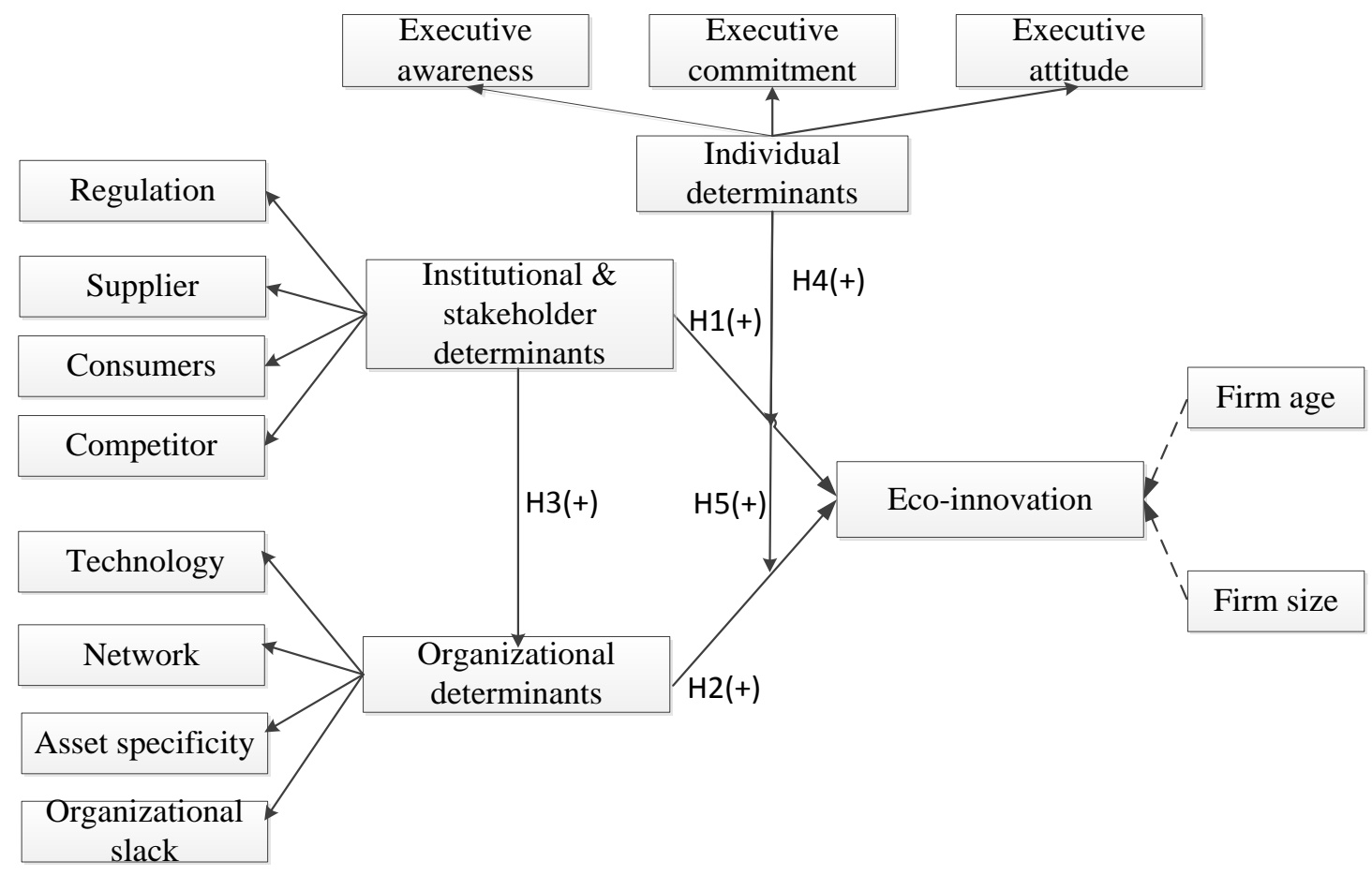

Figure 2-1 Conceptual Model of Eco-Innovation Determination 


\section{Data and methodology}

\subsection{Sample selection and variable description}

The data is based on questionnaire survey conducted in Wuhan city of Hubei province. Target population is project leaders who work in high technology firms such as electronics, IT, bioscience, advanced manufacturing, and new material/power firms since these firms are the most likely to adopt environmental practice due to nature of the industry and strategic need. Questionnaire survey was conducted through email and/or through on-site means. A total of 673 questionnaires were distributed and 326 were answered with a response rate of $48 \%$. After deduction of incomplete questionnaires, there remained 288 usable questionnaires. Latent variable of institutional and stakeholder determinants were paraphrased from Lin's (2014) work which include four items: regulation, supplier, consumers, and competition. The organizational drivers (4 items) and eco-innovation performance (4 items) were developed following Berrone (2013) and Cai and Zhou (2014). 7-point Likert scale ranging from 1 (strongly disagree) to 7 (strongly agree) was applied. For the moderator executive support, we developed three items through in-depth interview with the selected firm project managers. 7-point Likert scale was applied ranging from 1 (least) to 7 (most). Moreover, firm size (the log of firm total asset) and firm age were included as control variables.

\subsection{Test of reliability and validity}

Reliability was tested through Cronbach's alpha $(a)$ to assess whether items could represent latent variables accurately and stably. Convergent validity of the constructs was evaluated by factor loading. As indicated in Table 3-1, Cronbach's $a$ is between 0.767 and 0.904 which is bigger than suggested 0.7 by Nunnally (1978). All factor loadings exceeded 0.5 , showing acceptable convergent validity for one-order CFA (Hair 2006). 


\begin{tabular}{|c|c|c|c|}
\hline Construct & Measurement variables & $\begin{array}{c}\text { Factor } \\
\text { loading }\end{array}$ & $\begin{array}{c}\text { Cronbach } \\
\text { A }\end{array}$ \\
\hline \multirow{4}{*}{$\begin{array}{l}\text { Institutional/ } \\
\text { stakeholder } \\
\text { drivers(ISD) }\end{array}$} & National regulation formulated in the industry & 0.776 & \multirow[t]{4}{*}{0.844} \\
\hline & Supplier could offer eco-friendly materials and products & 0.814 & \\
\hline & Customer has environmental demand & 0.798 & \\
\hline & The competition is intense within the industry & 0.704 & \\
\hline \multirow{4}{*}{$\begin{array}{l}\text { Organizational } \\
\text { drivers } \\
\text { (OD) }\end{array}$} & Past R\&D experience/certain technology advantage & 0.647 & \multirow[t]{4}{*}{0.767} \\
\hline & Formal or informal network & 0.644 & \\
\hline & Possessing of specialized equipment or other fixed assets & 0.773 & \\
\hline & Sufficient working capital & 0.788 & \\
\hline \multirow{3}{*}{$\begin{array}{l}\text { Individual } \\
\text { drivers } \\
\text { (ID) }\end{array}$} & Executive environmental awareness & 0.816 & \multirow[t]{3}{*}{0.879} \\
\hline & Executive resource deploy commitment & 0.875 & \\
\hline & Executive attitude toward eco-innovation & 0.760 & \\
\hline \multirow{4}{*}{$\begin{array}{l}\text { Eco-innovation } \\
\text { Performance } \\
\text { (EP) }\end{array}$} & Environmental patent applications position among peers & 0.853 & \multirow[t]{4}{*}{0.904} \\
\hline & After-tax returns among peers & 0.845 & \\
\hline & Reductions of energy compared with peer firms & 0.793 & \\
\hline & Waste reduction ratio compares with peer firms & 0.775 & \\
\hline
\end{tabular}

Table 3-1 Test of reliability and validity

\section{Empirical results}

\subsection{Descriptive statistics}

Table 4-1 shows variable means, standard deviations, and correlations. We can tell from bivariate correlations that strong correlation exists between institutional/shareholder drivers and organizational drivers, organizational drivers and eco-performance, and weaker relationship exist between our expected moderators: individual drivers with institutional/shareholder drivers and organizational drivers. This confirms that our conceptual model set is appropriate. 


\begin{tabular}{|c|c|c|c|c|c|c|}
\hline $\begin{array}{c}\text { Variab } \\
\text { le }\end{array}$ & Mean & SD & ISD & OD & ID & $\begin{array}{l}E \\
P\end{array}$ \\
\hline ISD & 5.127 & 0.841 & 1 & & & \\
\hline OD & 5.091 & 0.938 & $\begin{array}{c}.498^{*} \\
*\end{array}$ & 1 & & \\
\hline ID & 5.212 & 1.060 & $\begin{array}{c}.462 * \\
*\end{array}$ & $\begin{array}{c}.413^{*} \\
*\end{array}$ & 1 & \\
\hline EP & 4.978 & 0.984 & $\begin{array}{c}.430 * \\
*\end{array}$ & $\begin{array}{c}.481 * \\
*\end{array}$ & $\begin{array}{c}.571 * \\
*\end{array}$ & 1 \\
\hline
\end{tabular}

${ }^{*}$ significant at $10 \%$ level; ${ }^{* *}$ significant at $5 \%$ level; ${ }^{* * *}$ significant at $1 \%$ level

Table 4-1 Descriptive Statistics

\subsection{Test for main effect and mediation effect}

First, we apply OLS regressions to test $\mathrm{H} 1$ and $\mathrm{H} 2$, and the results are presented in the second and third column of Table 4-2.

\begin{tabular}{|ccccc|}
\hline \multirow{2}{*}{ Variable } & \multicolumn{3}{c}{ Eco-performance } & OD \\
\cline { 2 - 5 } & Model 1 & Model 2 & Model 3 & Model 4 \\
\hline Size & $0.256^{*}$ & $0.238^{*}$ & $0.290^{*}$ & $0.312^{*}$ \\
\hline Age & $-0.147^{*}$ & $-0.053^{*}$ & $-0.049^{*}$ & $-0.135^{*}$ \\
\hline ISD & $0.503^{* * *}$ & & $0.299^{* * *}$ & $0.546^{* * *}$ \\
\hline OD & & $0.505^{* * *}$ & $0.373^{* * *}$ & \\
\hline R2 & 0.185 & 0.231 & 0.281 & 0.240 \\
\hline $\begin{array}{c}\text { Adjusted } \\
\text { R2 }\end{array}$ & $\begin{array}{c}0.182 \\
0.229\end{array}$ & 0.276 & 0.234 \\
\hline F & $\begin{array}{c}64.826^{* *} \\
{ }^{*}\end{array}$ & $\begin{array}{c}86.077^{* *} \\
*\end{array}$ & $\begin{array}{c}55.701^{* *} \\
*\end{array}$ & $\begin{array}{c}90.183^{* *} \\
*\end{array}$ \\
\hline
\end{tabular}

${ }^{*}$ significant at $10 \%$ level; ${ }^{* *}$ significant at $5 \%$ level; ${ }^{* * *}$ significant at $1 \%$ level

\section{Table 4-2 OLS Regression Results}

The significant coefficients 0.503 and 0.505 with significance level at $1 \%$ indicate that both institutional/stakeholder and organizational proxies are distinguished drivers of eco-innovation. Following the rationale of Baron and Kenny (1986), we need to perform another two regressions to test whether organizational impacts serve as a mediator. In model 3, we regress eco-performance 
on the combination of institutional/stakeholder and organizational proxies, and in model 4 we regress organizational driver on institutional/stakeholder factor in which a significant relationship exists (coefficient is 0.546 at $1 \%$ significance level). Presence of organizational driver in model 3 has made the coefficient of 0.503 drop to 0.299 for institutional/stakeholder on eco-innovation performance, thus, supporting the mediation effect of organizational drive. Furthermore, to test whether it is an absolute mediation or partial mediation, we compare the model fitting between partial mediation model and absolute mediation model using AMOS 17.0 (Table 4-3). From the model fitting indices, we can tell that partial and absolute mediation model outmatch direct effect model, combined with the still significant ISD indicator in Model 3 Table 4-4, we can arrive at the conclusion that organizational driver plays the role of partial mediation.

\begin{tabular}{|ccccc|}
\hline Model & X2/DF & GFI & AGFI & RMSEA \\
\hline Partial mediation & 2.049 & 0.949 & 0.917 & 0.060 \\
\hline Direct effect & 4.996 & 0.895 & 0.838 & 0.118 \\
\hline Absolute effect & 2.226 & 0.945 & 0.913 & 0.065 \\
\hline
\end{tabular}

Table 4-3 Model Fittings of Partial, Absolute Mediation Model and Direct Effect Model

Additionally, we apply hierarchical regressions to test the modulating effect of individual drivers. We mean-centered all interaction items to eliminate multi-collinearity. In Model 5 of Table 4-4, we introduce moderator individual impact proxy and institutional/stakeholder proxy in the model; and in Model 6, we introduce one additional interaction of individual impact proxy and institutional/stakeholder proxy. From the comparison of Model 5 and Model 6, we could tell that the entry of interaction term between ISD and ID could not add explaining power of the model and the moderation effect does not exist (the coefficient is 0.009 which could be ignored).

This proves that supervisory support cannot strengthen the relationship between institutional/stakeholder force and eco-innovation, so $\mathrm{H} 4$ has been rejected. Follow the same steps as used in Model 5 and 6, we test supervisory support interaction effect with organizational driver. On the contrary to our expectation, the interaction term has slightly significant negative effect on eco-innovation performance, hence $\mathrm{H} 5$ has been rejected. 


\begin{tabular}{|c|c|c|c|c|}
\hline \multirow[t]{2}{*}{ Variable } & \multicolumn{4}{|c|}{ Eco-performance } \\
\hline & Model5 & Model 6 & Model 7 & Model8 \\
\hline size & $0.145^{*}$ & $0.223^{*}$ & $0.178^{*}$ & $0.256^{*}$ \\
\hline age & -0.064 & $-0.070^{*}$ & $-0.067^{*}$ & $-0.093^{*}$ \\
\hline ISD & $\begin{array}{c}0.247^{* *} \\
*\end{array}$ & $0.248^{* * *}$ & & \\
\hline OD & & & $0.414^{* * *}$ & $\begin{array}{c}0.279^{* *} \\
*\end{array}$ \\
\hline ID & $\begin{array}{c}0.439^{* *} \\
*\end{array}$ & $0.439^{* * *}$ & $0.310^{* * *}$ & $\begin{array}{c}0.308^{* *} \\
*\end{array}$ \\
\hline ID*ISD & & 0.009 & & \\
\hline ID*OD & & & & $-0.136^{*}$ \\
\hline R2 & 0.361 & 0.361 & 0.398 & 0.412 \\
\hline $\begin{array}{c}\text { Adjusted } \\
\text { R2 }\end{array}$ & 0.356 & 0.354 & 0.394 & 0.409 \\
\hline$F$ & $\begin{array}{c}80.378 \\
* * * \\
\end{array}$ & $\begin{array}{c}53.417^{*} \\
* *\end{array}$ & $\begin{array}{c}94.257^{*} \\
* *\end{array}$ & $\begin{array}{c}97.832^{*} \\
* *\end{array}$ \\
\hline
\end{tabular}

${ }^{*}$ significant at $10 \%$ level; ${ }^{* *}$ significant at $5 \%$ level; ${ }^{* * *}$ significant at $1 \%$ level

Table 4-4 Hierarchical Regression Results

\section{Conclusion}

This study utilizes the rationale of institutional theory, stakeholder theory as well as upper echelons theory and combines these theories in a conceptualized model in exploring eco-innovation performance driving forces. Using questionnaire data from 288 enterprises to test the hypothetical model through Structural Equation Modeling analysis, we obtain several conclusions: both institutional/stakeholder force and organizational force are significant triggers in enterprise ecoinnovation, while the former one has indirect effect and latter one has direct effect. Supervisory support does not strengthen the relationship between institutional/stakeholder force and firm ecoinnovation but weaken the relationship between organizational driver and eco-innovation.

The results imply several suggestions pertinent to parties involved in enterprise eco-innovation:

1) Aside from being driven largely by external forces from regulation and stakeholder pressure, the adoption of eco-innovation in Chinese enterprise depends fundamentally on its organizational 
capability and resource. Firm should prepare its embracement with eco-economy transition through the perspectives of technological capability, scientific or social networking, resource base and asset specificity.

2) The facilitating role of supervisory support in enterprise eco-innovation should be played to full. As indicated from our empirical result, supervisory support proxy either has no influence or negatively modulates the relationship between organizational driver and eco-innovation. This surprising result is not uncommon in Chinese enterprise as many entrepreneurs are not evaluated by so called "green audit" or sanctioned fairly for environmental sabotage. The lack of incentive in eco-innovation makes them unwilling to perform environmental practices. Rather, they would apply organizational slack to maximize firm value.

3) It is highly imperative for policy makers and regulators to devote their efforts in three dimensions: optimize their regulation setting pertinent to micro level environmental protection, such as marketization of pollution permit design; implement more stringent regulation enforcement which presumably leads to higher environmental default cost; last but not least, combine the current administrative penalty and economic stimulation with potential informal regulation (such as environmental NGOs or voluntary environmental disclosure) and administrative stimulation (administrative acknowledgement or prize). This implies the mix of various approaches to incentivize enterprise eco-innovation.

\section{References}

- Bansal, P. From Issues to Actions: The Importance of Individual Concerns and Organizational Values in Responding to Natural Environmental Issues, Organization Sciences, 2003, 14(5):510527

- Baron, R. M., Kenny, D. A. The moderator-mediator variable distinction in social psychological research: conceptual, strategic, and statistical considerations, Journal of personality and social psychology, 1986, 51(6): 1173-1986

- Berrone P., Fosfuri A, Gelabert L, Gomez-Mejia L R. Necessity as the mother of 'green' inventions: institutional pressures and environmental innovations, Strategic Management Journal, 2013: 34:891-909

- Cai Wugan and Zhou Xiaoliang. On the drivers of eco-innovation: empirical evidence from China, Journal of Cleaner Production, 2014, 1-10

- Chang $\mathrm{CH}$. The influence of corporate environmental ethics on competitive advantage: the mediation role of green innovation, Journal of Business Ethics, 2011, 104(3): 361-370

- Cleff T, Rennings K. Determinants of environmental product and process innovation, European 
Environment, 1999, 9:191-201

- David, Gadenne; Jessica, Kennedy and Catherine, McKeiver. An Empirical Study of Environmental Awareness and Practices in Smes, Journal of Business Ethics, 2009, 84(1), 45-63

- De Marchi V. Environmental innovation and R\&D cooperation: Empirical evidence from Spanish manufacturing firms, Research Policy, 2012, 41(3): 614-623

- Frondel, M., Horbach, J., and Rennings, K.. End-of-pipe or cleaner production? An empirical comparison of environmental innovation decisions across OECD countries, Business Strategy and the Environment, 2007, 16: 571-584

- Frondel,M. Horbach, J. Rennings, K. What triggers environmental management and innovation? Empirical evidence for Germany, Ecological Economics, 2008, 66(1): 153-160

- Hair J. F., Black B., Babin B., Anderson R. E., Tatham, R.L. Multivariate data analysis sixth ed. Pearson Prentice Hall, Upper Saddle River, New Jersey, 2006

- Hofmann K. H., Theyel G., and Wood C. H., Identifying firm capabilities as drivers of environmental management and sustainability practices-evidence from small and medium-sized manufactures, Business strategy and environment, 2012, 21: 530-545

- Horbach J. Determinants of environmental innovation: New evidence from German panel data sources, Research Policy, 2008, 37:163-173

- Horbach, J., Rammer C., Rennings K. Determinants of eco-innovations by type of environmental impact - The role of regulatory push/pull, technology push and market pull, Ecological Economics, 2012, 78: 112-122

- Lin H. et al. Can political capital drive corporate green innovation? Lesson from China, Journal of cleaner production, 2014, 64: 63-72

- Nunnally, J. C. Psychometric Theory. New York, NY: McGraw-Hill, 1978

- Organization for Economic Co-operation and Development (OECD). Sustainable manufacturing and eco-innovation: framework, practices, and measurement. Synthesis Report. OECD, Paris, 2009

- Popp D. C. Induced innovation and energy prices, American Economic Review, 2002, 92:160180

- Popp D C. Pollution control innovations and the clean air act of 1990. Journal of Policy Analysis and Management, 2003, 22(4):641-660

- Porter, M.E. American's green strategy, Scientific American, 1991, 264(4): 168-176

- Rehfeld M M, Rennings K, Ziegler A. Integrated product policy and environmental product innovations: An empirical analysis. Ecological Economics, 2007, 61:91-100

- Ramus, C. A., Steger, U. The roles of supervisory support behaviors and environmental policy in employee "eco-initiatives" at leading-edge European companies. Academy of Management Journal, 2000, 43(4), 605-626 